\title{
Interferon- $\gamma$ liposome: a new system to improve drug delivery in the treatment of lung cancer
}

\author{
Maysa Alhawamdeh ${ }^{1}$, Mohammad Isreb ${ }^{2}$, Abid Aziz $^{3}$, Badie K. Jacob ${ }^{3}$, Diana Anderson ${ }^{1}$ and \\ Mojgan Najafzadeh ${ }^{1}$
}

${ }^{1}$ Division of Medical Sciences, Faculty of Life Sciences, University of Bradford, Bradford, UK. ${ }^{2}$ Faculty of Life Sciences, School of Pharmacy, University of Bradford, Bradford, UK. ${ }^{3}$ Bradford Royal Infirmary, Bradford Teaching Hospitals NHS Foundation Trust, Bradford, UK.

Corresponding author: Mojgan Najafzadeh (m.najafzadeh1@bradford.ac.uk)

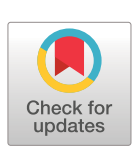

This version is distributed under the terms of the Creative Commons Attribution NonCommercial Licence 4.0. For commercial reproduction rights and permissions contact permissions@ersnet.org

This article has been revised according to the author correction published in ERJ Open Res 2021; 7: $50555-2020$

[https://doi.org/10.1183/

23120541.50555-2020].

Received: 5 Aug 2020

Accepted: 23 March 2021

First published: 23 Aug 2021

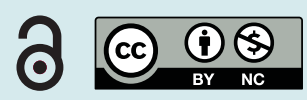

Shareable abstract (@ERSpublications)

A research article on the effect of bulk and nanoliposome interferon- $\gamma$ on lymphocytes from patients with lung cancer compared to healthy controls: assessing the ability of IFN- $\gamma$ liposome to reduce DNA damage more than the bulk form https://bit.ly/3wvfSyY

Cite this article as: Alhawamdeh M, Isreb M, Aziz A, et al. Interferon- $\gamma$ liposome: a new system to improve drug delivery in the treatment of lung cancer. ERJ Open Res 2021; 7: 2000555 [DOI: 10.1183/ 23120541.00555-2020].

\section{Abstract}

Lung cancer is one of the main causes of death worldwide. Published data show the use of interferons (IFNs) in treating lung tumours. IFNs also have potential for their antiproliferative, antiangiogenic, immunoregulatory and proapoptotic effects. IFN- $\gamma$ functions as an anticancer agent against various forms of cancer. This study aimed to investigate the effect of IFN- $\gamma$ liposome (nano) on peripheral lymphocytes from 20 individuals in each group: lung cancer patients compared to healthy individuals. The effectiveness of IFN- $\gamma$ liposome against oxidative stress was also evaluated in this study. A concentration of $100 \mathrm{U} \cdot \mathrm{mL}^{-1}$ of IFN- $\gamma$ liposome was used to treat the lymphocytes in the Comet and micronucleus assays based on the preliminary test for the optimal dose. The lymphocytes from lung cancer patients presented with higher DNA damage levels than those of healthy individuals. In healthy individuals, IFN- $\gamma$ liposome did not cause any DNA damage in the lymphocytes. Also, it caused a significant reduction in DNA damage in the lymphocytes from lung cancer patients in both the Comet and micronucleus assays. The $100 \mathrm{U} \cdot \mathrm{mL}^{-1}$ of IFN- $\gamma$ liposome significantly reduced the oxidative stress caused by $\mathrm{H}_{2} \mathrm{O}_{2}$ and appeared to be effective in both groups using the Comet and micronucleus assays. Results from both Comet and micronucleus assays were consistent. The data obtained indicated that IFN- $\gamma$ in both forms (IFN- $\gamma$ bulk and IFN- $\gamma$ nanoliposome) may potentially be effective for the treatment of lung cancer and showed the ability of IFN- $\gamma$ liposome to reduce DNA damage more than the bulk form.

\section{Introduction}

The term lung cancer encompasses epithelial cancers in the mucosa of the bronchi and sometimes in the parenchyma of the lung, which exists in the trachea (windpipe), bronchi (airways) or lung air sacs (alveoli) $[1,2]$. Lung cancer accounts for roughly $13 \%$ of annual cancer cases worldwide. It is also the second most common type of cancer in both males and females within the UK, although its incidence is higher in males than females [3]. In the UK, lung cancer is the leading reason for cancer death, with approximately 35000 deaths annually. The diagnostic peaks for lung cancer are between the ages of 73 and 84 years [4], and the overall 5 -year survival rate is less than $10 \%$, mainly because the majority of patients present with a late phase of the disease, a point at which treatment has little impact on survival [5]. This cancer could be developed or extended to the airways, resulting in symptoms such as cough, airway obstruction and haemoptysis. The tumour can metastasise to the thorax area, causing compression. It might also invade the chest wall and extend further, via the hilar, mediastinal and supraclavicular nodes [6]. Furthermore, it enhances transformations in the central or peripheral nervous system, leading to anorexia and causing a disturbance in hormone production. Cancer metastasises via the blood to different parts of the body, specifically to the liver, brain, adrenal gland and axial skeleton [7]. 
Studies have shown that cigarette smoking is the main risk factor in lung cancer patients. Current smokers have a 15-fold increase in risk of death from lung cancer compared with lifelong nonsmokers [8]. On the other hand, this risk decreases significantly in individuals who cease smoking before middle age [9]. The risk of lung cancer is also elevated following exposure to environmental tobacco smoke (ETS). An estimated $14-15 \%$ of lung cancers are caused by exposure to ETS [10]. 85\% of lung cancer patients have nonsmall cell lung cancer (NSCLC), including adenocarcinoma, adenosquamous cell carcinoma, squamous cell carcinoma and large cell carcinoma.

IFN- $\gamma$ is produced mainly by Th1 CD4+ T cells, CD8+ T cells and natural killer (NK) cells. Additionally, recent studies have indicated that other cells such as B cells, natural killer T (NKT) cells and professional antigen-presenting cells (APCs) may also be a source of IFN- $\gamma$. This secretion is controlled primarily by IL-12 and IL-18 [11]. IFN- $\gamma$ has major antiviral, immunoregulatory and antitumour roles, through interaction with specific cell-surface receptors, including four transmembrane polypeptide receptor complexes: two ligand-binding chains (IFN- $\gamma$ R1) and two signal-transducing chains (IFN- $\gamma$ R2), which are required for signal transduction [12]. The most critical transduction pathway stimulated by IFN- $\gamma$ is the Janus kinase (Jak)/signal transducer and activator of transcription 1 (STAT1) pathway. This contributes to the antiproliferative effects of IFN- $\gamma$ on different cell types, as it has been elucidated that both pathways have the potential to inhibit tumour progression and kill pathogen-infected cells [13]. This is done by binding two IFN- $\gamma$ R2 subunits with two IFN- $\gamma$-bound IFN- $\gamma$ R1 chains [14]. After the receptor complex association is induced, Jak1 and Jak2 activate and phosphorylate Tyr440 of IFN- $\gamma$ R1, forming a docking site for STAT1. STAT1 is activated by phosphorylation at Tyr701, leading to homodimerisation of STAT1 and nuclear translocation. The STAT1 dimers interact with specific DNA sequences called IFN- $\gamma$-activated sequences (GAS), present in the promoter regions of IFN-stimulated genes, and responsible for regulating their transcription $[15,16]$. The entirety of these mechanisms are presented in figure 1 [17].

The transcriptional activity of STAT1 is stimulated through kinases. These kinases are mitogen-activated protein kinase (MAPK), protein kinase C (PKC) and phosphoinositide 3-kinase (PI3K)/AKT, which phosphorylates STAT1 in the transactivation domain [17]. The mechanism of the STAT1 pathway plays a positive role by regulating the expression of genes encoding several antiproliferative and proapoptotic molecules, such as IFN regulatory factor 1 (IRF-1). However, if IRF-1 is inhibited, the IFN- $\gamma$ activates the proliferative signals. On the other hand, when the IRF-1 is elevated, the IFN- $\gamma$ stimulates apoptotic signals $[18,19]$. In mice, those with deficient IFN- $\gamma$ spontaneously develop lung epithelial malignancies and lymphoma. Furthermore, mice with a deficient IFN- $\gamma$ receptor and STAT1 manifest tumour growth following chemical carcinogen treatment, which emphasises the ability of IFN- $\gamma$ to act as an anticancer agent [20]. Furthermore, preliminary research indicates that IFN- $\gamma$, given as a single agent, has a measurable effect as an antitumour agent in advanced NSCLC [21].

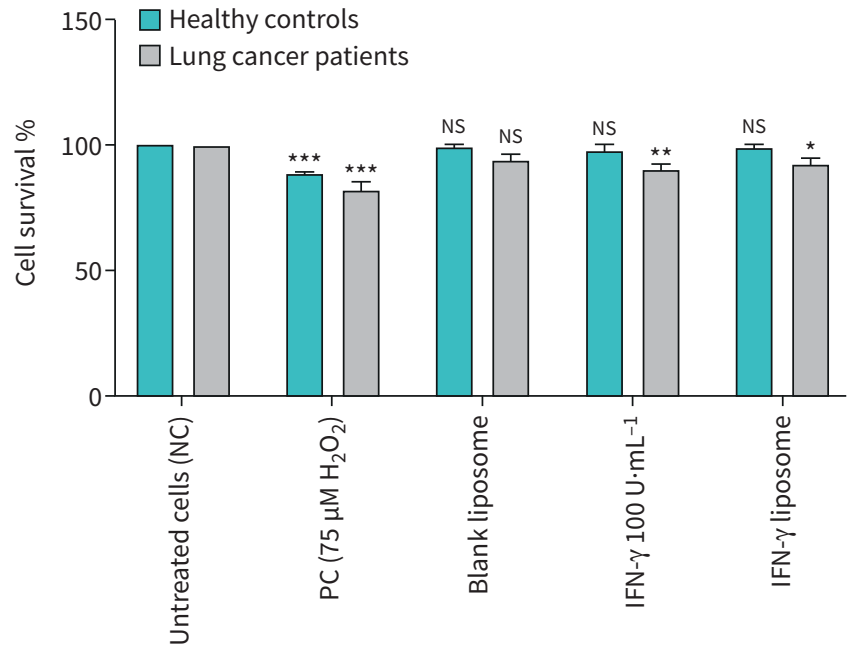

Treatment groups

FIGURE 1 Per cent survival in $10 \times 10^{4}$ cells of various test treatments in lymphocytes from healthy individuals and lung cancer patients using CCK-8 assay. Error bars show mean values \pm SE, $n=3$. NC: nucleated cell; PC: positive control; IFN: interferon; Ns: nonsignificant. ${ }^{\star}$ : $p<0.05 ;{ }^{\star \star}: p<0.01 ;{ }^{\star \star \star}: p<0.001$. 
Liposomes are artificial vesicles made from single or multiple phospholipid layers (lamellas) with spherical, self-assembled shapes. Their sizes typically range from tens of nanometres up to hundreds of micrometres, depending on their preparation methods [22, 23]. They can also be made from nontoxic surfactants, cholesterols and membrane proteins [24]. Liposomes have been used extensively as drug delivery carriers and utilised for biomedical and biotechnological purposes [25]. The encapsulation of the drug into liposomes can reduce the toxicity, enhance the pharmacokinetics of the drug and result in more efficient therapeutic effects [26].

Moreover, liposomes can increase bioavailability and improve the solubility of poorly water-soluble drugs [5]. A recent study adopted the IFN- $\gamma$ liposome-based drug delivery method by modifying it with cyclic peptides in order to initiate an antifibrotic effect for the therapy of hepatic fibrosis in the rat. It was found that the sterically modified IFN- $\gamma$ liposomes have a greater antifibrotic effect of activating the hepatic stellate cells by 7.24-fold and 2.95-fold compared to free IFN- $\gamma$, with fewer adverse side-effects [27].

The primary objective of this research was to study the DNA protective effect of IFN- $\gamma$ bulk and IFN- $\gamma$ liposome on lymphocytes from lung cancer patients compared to healthy individuals.

In this study, the effect of IFN- $\gamma$ bulk and IFN- $\gamma$ liposome on DNA damage was detected in peripheral blood lymphocytes of lung cancer patients and healthy individuals by using the Comet micronucleus assay. The Comet assay was used in this study due to its sensitivity and simplicity for analysis of the genotoxicity of DNA in lymphocytes as presented in previous studies [28-30].

\section{Materials and methods}

Materials

IFN- $\gamma$ ( $\geqslant 98 \%$ purity; Cat No. 17001), Mitomycin C (MMC) (Cat No. M0503) and fetal bovine serum (FBS) (Cat No. F7524) were purchased from Sigma-Aldrich (Gillingham, UK). RPMI 1640 Medium (RPMI-1640) (Cat No. R8758), phytohaemagglutinin (PHA) (Cat No. L1668) and penicillin-streptomycin solution (Cat No. P4333) were also obtained from Sigma-Aldrich. All other chemicals used in the different tests were from Sigma-Aldrich Company Ltd. (Sigma Chemical Ltd., Gillingham, UK). Prior to using the IFN- $\gamma$, the lyophilised powder was reconstituted in double distilled water to form the stock solution. It was then diluted in RPMI-1640 Medium with $10 \%$ FBS and stored at $-20^{\circ} \mathrm{C}$.

The dose-response experiments were carried out to determine the optimal doses of IFN- $\gamma$ bulk and liposome and $\mathrm{H}_{2} \mathrm{O}_{2}$ used throughout the study. A fixed dose of both forms $\left(100 \mathrm{U} \cdot \mathrm{mL}^{-1}\right.$ of IFN- $\gamma$ bulk and $100 \mathrm{U} \cdot \mathrm{mL}^{-1}$ of IFN- $\gamma$ liposome) were used as treatment. The classic genotoxic compound hydrogen peroxide $\left(\mathrm{H}_{2} \mathrm{O}_{2}\right)(75 \mu \mathrm{M})$ was used as a positive control (PC).

\section{Preparation and characterisation of liposomes}

Liposomes were prepared using the thin film rehydration method. 1,2-Dipalmitoyl-sn-glycero-3phospho-rac-(1-glycerol) sodium salt (DPPG), 1,2-dioleoyl-sn-glycero-3-phosphoethanolamine (DOPE) and cholesterol were dissolved in dichloromethane (DCM) and methanol (3:1 v/v). The solution was then transferred to a rotary evaporator with a $25 \mathrm{~mL}$ round-bottomed flask. The organic solvent mixture was evaporated at $40^{\circ} \mathrm{C}$ under vacuum for $6 \mathrm{~h}$, to ensure no traces of the organic solvents were left. The thin film was then hydrated by $10 \mathrm{~mL}$ of PBS solution of IFN- $\gamma$ for $1 \mathrm{~h}$ at $60^{\circ} \mathrm{C}$ using a bath sonicator $(150 \mathrm{~W})$. The sample was then subjected to four repeated freeze-thaw cycles (freezing at $-20^{\circ} \mathrm{C}$ and thawing at $60^{\circ} \mathrm{C}$ in the bath sonicator). Furthermore, the blank liposome was prepared from the same components without adding the IFN- $\gamma$.

Average size and polydispersity index (PDI) of the liposome preparations were determined by dynamic light scattering (DLS) using Zetasizer ZS (Malvern Instruments, UK). All measurements were performed in triplicate.

\section{Ethical approval}

Ethical approval was obtained to execute the Comet and micronucleus assays for the study of IFN- $\gamma$ and IFN- $\gamma$ liposome. This study received ethical approval from Leeds East Research Ethics Committee (REC number: 12/YH/0464), the University of Bradford Research Ethics Sub-Committee on Research in Human Subjects (Ref: 0405/8) and the Research Support and Governance Office, Bradford Teaching Hospitals, NHS Foundation (Ref: RE DA 1202). 
Sample preparation and Comet assay

After obtaining consent from healthy nonsmoking volunteers and lung cancer patients, whole blood samples were collected by venepuncture in $9 \mathrm{~mL}$ lithium heparin-coated tubes and clearly labelled for ease of identification. Samples were diluted in a ratio of 1:1 with RPMI-1640 Medium, and then mixed with $10 \%$ dimethyl sulfoxide (DMSO). The diluted blood solution was divided and transferred to labelled $1.5 \mathrm{~mL}$ Eppendorf ${ }^{\circledR}$ tubes, which were closed tightly and stored at $-80^{\circ} \mathrm{C}$.

The Comet assay was prepared according to [31, 32]. In brief, $100 \mu \mathrm{L}$ of whole blood samples were incubated for $30 \mathrm{~min}$ at $37^{\circ} \mathrm{C}$ with different test agents, to make the final volume of $1000 \mu \mathrm{L}$ with RPMI1640 Medium (with sodium bicarbonate, without L-glutamine, liquid, sterile-filtered, suitable for cell culture). The test agents included a PC of $75 \mu \mathrm{M} \mathrm{H}_{2} \mathrm{O}_{2}$, blank liposome IFN- $\gamma 100 \mathrm{U} \cdot \mathrm{mL}^{-1}$ and IFN- $\gamma$ liposome in order to test the effect of IFN- $\gamma$ in a highly oxidising environment; $100 \mathrm{U} \cdot \mathrm{mL}^{-1}$ of IFN- $\gamma$ and IFN- $\gamma$ liposome were treated in the presence of $75 \mathrm{mM} \mathrm{H}_{2} \mathrm{O}_{2}$. An untreated sample was used as a negative control. The samples were then incubated at $37^{\circ} \mathrm{C}$ for $30 \mathrm{~min}$. Following incubation, the samples were centrifuged at $3000 \mathrm{rpm}$ for $5 \mathrm{~min}$. The method used thereafter was followed as described in [28-30].

The slides were coded before scoring; per slide, 100 nuclei were scored using a fluorescent microscope at 20× magnification. This was connected to a CCD camera using Komet 6 software and Kinetic Imaging (Andor Technology Ltd, Belfast). Olive tail moment (OTM) and \% tail DNA were used simultaneously to decrease variability in the results [33].

\section{The cytokinesis block micronucleus (CBMN) assay}

Whole blood $(500 \mu \mathrm{L})$ was added to a T25 $\mathrm{cm}^{2}$ Corning culture flask containing $4.5 \mathrm{~mL}$ RPMI-1640 Medium supplemented with 1\% penicillin-streptomycin, 15\% FBS and 25 mM HEPES and L-glutamine with end concentrations of $15 \%$ and $1 \%$, respectively, followed by $100 \mu \mathrm{L}$ of phythaemagglutinin (PHA) (2.5\%). In the next $24 \mathrm{~h}, 50 \mu \mathrm{L}$ of blank liposome was added to the negative control. Two positive controls were used with $10 \mu \mathrm{L}$ of MMC $(0.4 \mu \mathrm{M})$ used as PC 1 , and $50 \mu \mathrm{L}$ of $\mathrm{H}_{2} \mathrm{O}_{2}$ served as PC 2. $50 \mu \mathrm{L}$ of $100 \mathrm{U} \cdot \mathrm{mL}^{-1} \mathrm{IFN}-\gamma$ and IFN- $\gamma$ liposome were added to their respective flasks and the final flask contained IFN- $\gamma$ liposome and $\mathrm{H}_{2} \mathrm{O}_{2}$. $50 \mu \mathrm{L}$ of cytochalasin-B $\left(6 \mu \mathrm{g} \cdot \mathrm{mL}^{-1}\right.$, Sigma) was added to each flask and cultured at $37^{\circ} \mathrm{C}$ in the presence of $5 \% \mathrm{CO}_{2}$ for $44 \mathrm{~h}$. The CBMN procedures were performed as described by FENECH and coworkers [34, 35].

Numerous cytological scoring parameters were used to assess DNA damage. Micronuclei (MNi) were scored from both binucleated cells (BiNCs) and mononucleated cells (MonoNCs). Nucleoplasmic bridges (NPBs) and nuclear buds (NBUDs) were only scored for BiNC [36]. The nuclear division index (NDI) was calculated using the equation $\mathrm{NDI}=\mathrm{M} 1+2(\mathrm{M} 2)+3(\mathrm{M} 3) / \mathrm{N}$, where $\mathrm{M} 1=$ =mononucleated cells, $\mathrm{M} 2=$ binucleated cells, M3=multinucleated cells and N=total number of viable cells scored [35].

\section{Cell viability}

The viability of cells was detected after $30 \mathrm{~min}$ of incubation of cells with different concentrations of treatments. Lymphocytes were isolated from whole blood using ficoll-paque as described in [37]. Cell viability was then determined by the trypan blue staining method described in [38] and the Cell Counting Kit-8 (CCK-8) method [39]. The concentrations with cell viability of $\geqslant 75 \%$ were used in all experiments [40].

\section{Statistical analysis}

The final data were expressed as mean values with standard errors, the results were analysed using one-way ANOVA with Dunnett's multiple comparisons test using GraphPad Prism 8.1.2. p-values were considered significant at $\mathrm{p}<0.05, \mathrm{p}<0.01, \mathrm{p}<0.001$.

\section{Results}

The viability of lymphocytes from healthy individuals and lung cancer patients was assessed after treatment with chemicals used in this study was between $75 \%$ and $85 \%$ using trypan blue dye exclusion. The viability of lymphocytes from healthy individuals and lung cancer patients treated with different treatment groups was also confirmed using the CCK-8 assay $\geqslant 75$ after $24 \mathrm{~h}$ treatment (figure 1).

\section{Comet assay: IFN- $\gamma$ liposome versus bulk}

The data from the Comet assay results showed that lung cancer patient lymphocytes were more susceptible to DNA damage than healthy individuals, in \% tail DNA and OTM, when compared with groups that received no treatment $(p<0.001)$ as presented in table 1 , figures 2 and 3 . A significant increase in \% tail DNA and OTM in lymphocytes from healthy volunteers and lung cancer patients after exposure to PC $\left(75 \mu \mathrm{M} \mathrm{H}_{2} \mathrm{O}_{2}\right)(\mathrm{p} \leqslant 0.001)$ (figures 2 and 3$)$. 


\begin{tabular}{|c|c|c|c|c|}
\hline \multirow[t]{2}{*}{ Treatments } & \multicolumn{2}{|c|}{ Healthy individuals } & \multicolumn{2}{|c|}{ Lung cancer patients } \\
\hline & $\%$ tail DNA & Mean OTM \pm SEM & $\%$ tail DNA & Mean OTM \pm SEM \\
\hline Untreated cells (NC) & $8.257 \pm 0.32$ & $1.367 \pm 0.05$ & $10.97 \pm 0.52$ & $2.18 \pm 0.15$ \\
\hline $\mathrm{PC}-75 \mu \mathrm{M} \mathrm{H} \mathrm{O}_{2}$ & $15.61 \pm 0.83^{\star \star \star}$ & $3.25 \pm 0.34^{\star \star \star}$ & $15.69 \pm 0.71^{\star \star \star}$ & $3.32 \pm 0.2^{\star \star \star}$ \\
\hline Blank liposome & $9.76 \pm 0.43 \mathrm{NS}$ & $1.57 \pm 0.12 \mathrm{NS}$ & $9.87 \pm 0.29 \mathrm{NS}$ & $1.71 \pm 0.08 \mathrm{NS}$ \\
\hline IFN- $\gamma 100 \mathrm{U} \cdot \mathrm{mL}^{-1}$ & $7.73 \pm 0.31 \mathrm{NS}$ & $1.26 \pm 0.06 \mathrm{NS}$ & $8.42 \pm 0.32^{\star \star \star}$ & $1.38 \pm 0.07^{\star \star \star}$ \\
\hline IFN- $\gamma$ liposome & $6.70 \pm 0.24 \mathrm{NS}$ & $1.05 \pm 0.05 \mathrm{NS}$ & $6.65 \pm 0.34^{\star \star \star}$ & $1.07 \pm 0.07^{\star \star \star}$ \\
\hline IFN- $\gamma$ liposome $+\mathrm{H}_{2} \mathrm{O}_{2}$ & $8.53 \pm 0.36 \mathrm{NS}$ & $1.41 \pm 0.08 \mathrm{NS}$ & $8.61 \pm 0.38^{\star \star \star}$ & $1.49 \pm 0.09^{\star \star}$ \\
\hline IFN- $\gamma 100 \mathrm{U} \cdot \mathrm{mL}^{-1}+\mathrm{H}_{2} \mathrm{O}_{2}$ & $8.67 \pm 0.33 \mathrm{NS}$ & $1.45 \pm 0.06 \mathrm{NS}$ & $8.87 \pm 0.29^{\star}$ & $1.54 \pm 0.06^{\star}$ \\
\hline
\end{tabular}

Lymphocytes obtained from 20 healthy individuals (figures 2 and 3) showed that $100 \mathrm{U} \cdot \mathrm{mL}^{-1} \mathrm{IFN}-\gamma$ bulk and IFN- $\gamma$ liposome was clearly unaffected in lymphocyte cells when measuring \% tail DNA and OTM compared to untreated cells. In contrast, the $\mathrm{H}_{2} \mathrm{O}_{2}$-induced DNA damage was significantly reduced by $100 \mathrm{U} \cdot \mathrm{mL}^{-1}$ IFN- $\gamma$ bulk and IFN- $\gamma$ liposome in lymphocytes from healthy individuals compared to the PC $\left(75 \mu \mathrm{M} \mathrm{H}_{2} \mathrm{O}_{2}\right)(\mathrm{p} \leqslant 0.001)$. In contrast, IFN- $\gamma$ liposome was more effective in reducing the DNA damage than IFN- $\gamma$ bulk, as presented in table 1 .

Lymphocytes from lung cancer patients $(n=20)$ also showed a significant decrease in \% tail DNA and OTM from 10.97\% (\% tail DNA) and 2.18 (OTM) compared to the untreated control groups to 8.42\% (\% tail DNA) and 1.38 (OTM), respectively, when cells were treated with IFN- $\gamma$ bulk whereas the reduction in $\%$ tail DNA and OTM was more effective by using IFN- $\gamma$ liposome, which showed a significant decrease

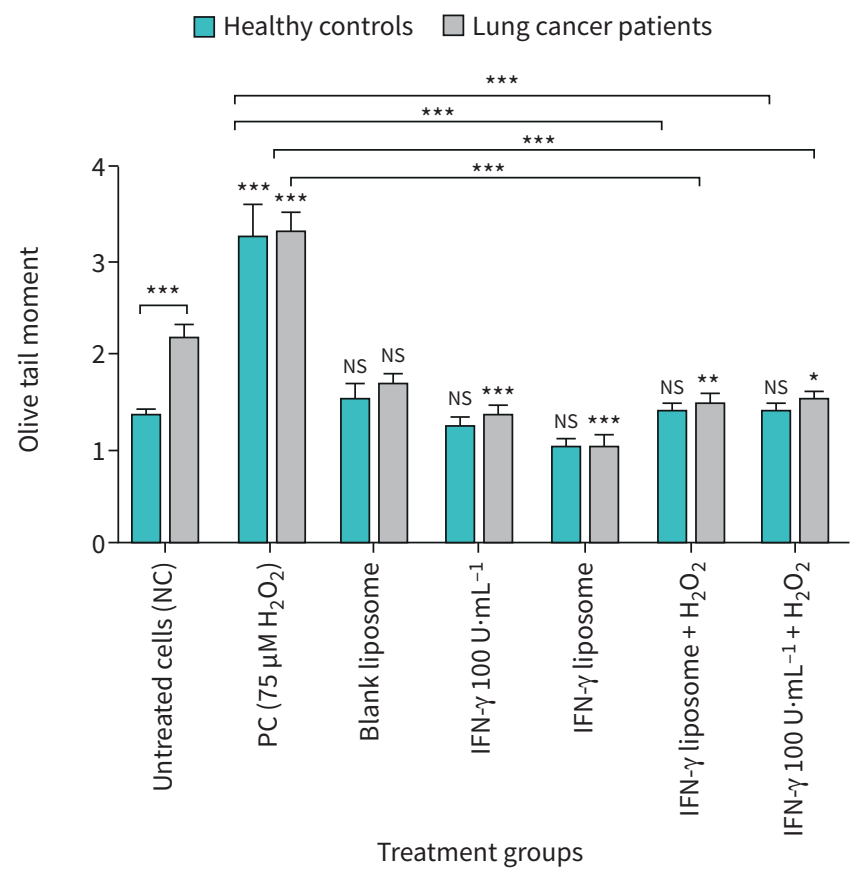

FIGURE 2 DNA damage measured as mean olive tail moment before and after treatment with bulk and liposome forms of interferon (IFN)- $\gamma$ in human lymphocytes from healthy individuals and lung cancer patients in the Comet assay. $n=20$ in each group. NC: nucleated cells; PC: positive control; Ns: nonsignificant. *: $p<0.05$; ${ }^{* *}: p<0.01 ;{ }^{* * *}: p<0.001$. 
Healthy controls $\square$ Lung cancer patients

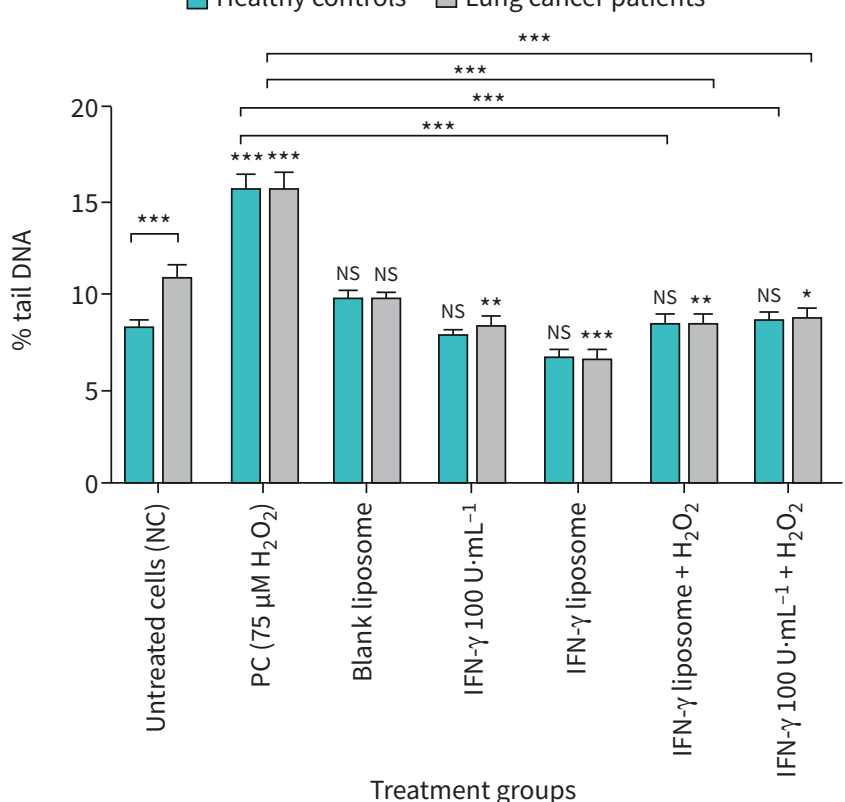

FIGURE 3 DNA damage measured as mean \% tail DNA before and after treatment with bulk and liposome forms of interferon (IFN) $-\gamma$ in human lymphocytes from healthy individuals and lung cancer patients in the Comet assay. $\mathrm{n}=20$ in each group. NC: nucleated cells; PC: positive control; ns: nonsignificant. *: $p<0.05$; ${ }^{\star *}: p<0.01 ;{ }^{* \star *}: p<0.001$.

in \% tail DNA 6.65\% and 1.07 (OTM). Furthermore, cells treated with IFN- $\gamma$ bulk and IFN- $\gamma$ liposome co-supplemented with $75 \mu \mathrm{M} \mathrm{H}_{2} \mathrm{O}_{2}$ showed significant decreases in OTM and \% tail DNA compared to the PC $\left(75 \mu \mathrm{M} \mathrm{H}_{2} \mathrm{O}_{2}\right)(\mathrm{p} \leqslant 0.001)$.

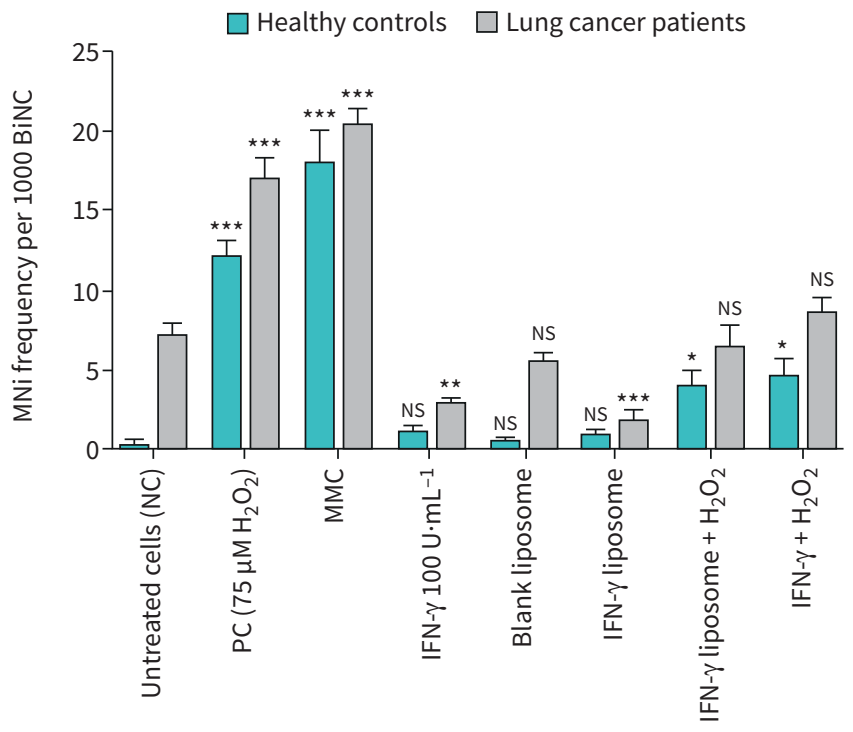

Treatment groups

FIGURE 4 Comparison of MNi frequencies between healthy individuals and lung cancer patients, after treatment with $75 \mu \mathrm{M} \mathrm{H}_{2} \mathrm{O}_{2}, 0.4 \mu \mathrm{M}$ Mitomycin C (MMC), $100 \mathrm{U} \cdot \mathrm{mL}^{-1}$ of interferon (IFN)- $\gamma$ bulk, IFN- $\gamma$ liposome and $100 \mathrm{U} \cdot \mathrm{mL}^{-1}$ of IFN- $\gamma$ bulk, IFN- $\gamma$ liposome in the presence of $75 \mu \mathrm{M} \mathrm{H}_{2} \mathrm{O}_{2} . \mathrm{n}=5$ in each group. BiNC: binucleated cells; NC: nucleated cells; PC: positive control; ns: nonsignificant. *: $p<0.05 ;{ }^{* *}: p<0.01 ;{ }^{* *}$ : $p<0.001$. 
CBMN: effect of IFN- $\gamma$ liposome

The lymphocytes from healthy individuals and lung cancer patients were treated with $75 \mu \mathrm{M} \mathrm{H}_{2} \mathrm{O}_{2}, 0.4 \mu \mathrm{M}$ MMC, $100 \mathrm{U} \cdot \mathrm{mL}^{-1}$ of IFN- $\gamma$ bulk, IFN- $\gamma$ liposome and $100 \mathrm{U} \cdot \mathrm{mL}^{-1}$ of IFN- $\gamma$ bulk, IFN- $\gamma$ liposome with $75 \mu \mathrm{M} \mathrm{H}_{2} \mathrm{O}_{2}$. They were then assessed for MNi induction using the CBMN assay, as presented in figure 4 . In contrast, lymphocytes from healthy individuals treated with $100 \mathrm{U} \cdot \mathrm{mL}^{-1}$ of IFN- $\gamma$ bulk and IFN- $\gamma$ liposome showed no effect on MNi frequency compared to untreated cells. The MMC and $75 \mu \mathrm{M} \mathrm{H}_{2} \mathrm{O}_{2}$ displayed a significant increase in the MNis of lymphocytes $(\mathrm{p}<0.001)$, but $100 \mathrm{U} \cdot \mathrm{mL}^{-1}$ of IFN- $\gamma$ bulk and IFN- $\gamma$ liposome co-supplemented with $\mathrm{H}_{2} \mathrm{O}_{2}$ showed a significant decrease in MNis of lymphocytes $(\mathrm{p}<0.05)$ as in figure 4 . It was evident that the $100 \mathrm{U} \cdot \mathrm{mL}^{-1}$ of IFN- $\gamma$ bulk and IFN- $\gamma$ liposome showed a significant reduction in the number of MNis in lung cancer patients, but the reduction by IFN- $\gamma$ liposome was greater $(\mathrm{p}<0.001)$ compared to untreated cells. Furthermore, the MMC and $75 \mu \mathrm{M} \mathrm{H}_{2} \mathrm{O}_{2}$ showed a significant increase $(\mathrm{p}<0.001)$ in the MNi number on lymphocytes compared to the untreated cells.

There are numerous cytological scoring parameters, including biomarkers of cell mitotic division such as mononucleated cells (MoNCs), binucleated cells (BiNCs) and multinucleated cells (MultiNCs). From these parameter values, the NDI was calculated for healthy individuals and lung cancer patients, respectively. The mean values for the NDI for all treatment groups were within the normal range, as shown in table 2 . Table 2 also displays the chromosomal instability parameters in the form of the mean of NPBs, NBUDs per $1000 \mathrm{BiNC}$ and MNi frequency in MoNC. The table clearly shows that the frequency of MNi in BiNC of untreated cells is higher than in lymphocytes treated with IFN- $\gamma$ liposome on lung cancer patients.

\section{Discussion}

This study investigated the efficacy of IFN- $\gamma$ and IFN- $\gamma$ liposome in human lymphocytes originating from groups of 20 healthy individuals and 20 lung cancer patients, using the Comet assay and five individuals in each group for the CBMN assay. Different in vitro and in vivo studies have shown the promising applications of IFN- $\gamma$ in the field of health as a treatment displaying pleiotropic immunomodulatory, antiviral, antimicrobial, antineoplastic, proinflammatroy activities [12]. Furthermore, the potent inhibitory effects of IFN- $\gamma$ in various tumour models, such as bladder carcinoma, colorectal cancer, ovarian cancer, and adult T cell leukaemia, human pancreatic carcinoma cells, and NSCLC have been evidenced [11, 17].

Research has demonstrated that IFN- $\gamma$ can induce apoptosis in human glioblastoma T98G and U87MG cells [41], and inhibited the proliferation of four pancreatic cancer cell lines in vitro [42]. Other studies indicated that IFN- $\gamma$ was responsible for apoptosis in ovarian cancer cells in vivo and in vitro [43]. By contrast, none of the previous studies has focused on the effect of IFN- $\gamma$ on DNA damage in human lymphocytes from lung cancer patients through the use of the Comet and CBMN assay.

TABLE 2 The mean of different parameters for chromosomal damage in healthy individuals and lung cancer patients lymphocyte using the cytokinesis block micronucleus assay

\begin{tabular}{|c|c|c|c|c|c|c|c|c|}
\hline \multirow[t]{2}{*}{ Subject } & \multirow[t]{2}{*}{ Treatment group } & \multirow[t]{2}{*}{ Mean of NDI } & \multirow[t]{2}{*}{ Mean of $\%$ BiNC } & \multirow[t]{2}{*}{ Mean of $\%$ MultiNC } & \multicolumn{3}{|c|}{ Mean per 1000 BiNC cells } & \multirow{2}{*}{$\begin{array}{l}\text { Mean of \% } \\
\text { MNi in MoNC }\end{array}$} \\
\hline & & & & & BiMNi & BiNPB & BiBuds & \\
\hline \multirow[t]{8}{*}{ Healthy volunteers } & Untreated lymphocytes & $1.92 \pm 0.03$ & $60.6 \pm 1.6$ & $16.2 \pm 1.15$ & $0.4 \pm 0.24$ & 0 & 0 & 0 \\
\hline & $75 \mu \mathrm{M} \mathrm{H}_{2} \mathrm{O}_{2}$ & $1.96 \pm 0.03$ & $60.6 \pm 0.4$ & $18.4 \pm 1.56$ & $12.2 \pm 1.11$ & $0.2 \pm 0.2$ & 0 & $6.2 \pm 1.59$ \\
\hline & $0.4 \mu \mathrm{M} M M C$ & $1.88 \pm 0.06$ & $59.2 \pm 2.4$ & $15.6 \pm 3.81$ & $18.0 \pm 2.09$ & 0 & 0 & $8.4 \pm 1.8$ \\
\hline & $100 \mathrm{U} \cdot \mathrm{mL}^{-1}$ IFN- $\gamma$ & $1.87 \pm 0.02$ & $58.8 \pm 0.58$ & $14.2 \pm 1.2$ & $1.4 \pm 0.24$ & 0 & 0 & $1.2 \pm 0.37$ \\
\hline & Blank liposome & $1.93 \pm 0.04$ & $60.2 \pm 1.68$ & $17.0 \pm 1.51$ & $0.4 \pm 0.24$ & 0 & 0 & 0 \\
\hline & IFN- $\gamma$ liposome & $1.98 \pm 0.03$ & $61.6 \pm 0.4$ & $19.4 \pm 1.4$ & $1.2 \pm 0.2$ & 0 & 0 & $0.6 \pm 0.4$ \\
\hline & IFN- $\gamma$ liposome $+\mathrm{H}_{2} \mathrm{O}_{2}$ & $1.96 \pm 0.02$ & $59.0 \pm 2.28$ & $19.8 \pm 2.72$ & $4.2 \pm 0.86$ & 0 & 0 & $3.2 \pm 1.28$ \\
\hline & IFN- $\gamma+\mathrm{H}_{2} \mathrm{O}_{2}$ & $1.92 \pm 0.07$ & $59.6 \pm 1.91$ & $17.6 \pm 4.45$ & $4.8 \pm 0.96$ & 0 & 0 & $4.4 \pm 1.43$ \\
\hline \multirow[t]{8}{*}{ Lung cancer patients } & Untreated lymphocytes & $1.90 \pm 0.03$ & $58.4 \pm 2.2$ & $16.4 \pm 1.43$ & $7.4 \pm 0.6$ & $0.2 \pm 0.2$ & 0 & $3.4 \pm 0.4$ \\
\hline & $75 \mu \mathrm{M} \mathrm{H}_{2} \mathrm{O}_{2}$ & $1.89 \pm 0.03$ & $56.0 \pm 2.46$ & $17.0 \pm 2.07$ & $17.0 \pm 1.3$ & $0.6 \pm 0.4$ & 0 & $6.4 \pm 1.2$ \\
\hline & $0.4 \mu \mathrm{M} M M C$ & $1.93 \pm 0.02$ & $58.0 \pm 2.44$ & $18.0 \pm 1.51$ & $20.6 \pm 0.81$ & $1.8 \pm 0.8$ & $0.2 \pm 0.2$ & $9 \pm 1.76$ \\
\hline & $100 \mathrm{U} \cdot \mathrm{mL}^{-1} \mathrm{IFN}-\gamma$ & $1.97 \pm 0.03$ & $59.6 \pm 0.5$ & $19.2 \pm 1.59$ & $3.0 \pm 0.31$ & 0 & 0 & $3 \pm+0$ \\
\hline & Blank liposome & $1.91 \pm 0.02$ & $60.8 \pm 0.86$ & $15.2 \pm 1.42$ & $5.6 \pm 0.4$ & $0.2 \pm 0.2$ & 0 & $3.2 \pm 0.48$ \\
\hline & IFN- $\gamma$ liposome & $1.87 \pm 0.04$ & $57.8 \pm 1.24$ & $15.2 \pm 2.2$ & $2.2 \pm 0.37$ & 0 & 0 & $1.8 \pm 0.2$ \\
\hline & IFN- $\gamma$ liposome $+\mathrm{H}_{2} \mathrm{O}_{2}$ & $1.99 \pm 0.03$ & $58.6 \pm 2.18$ & $21.0 \pm 2.6$ & $6.6 \pm 1.2$ & 0 & 0 & $4 \pm 0.7$ \\
\hline & IFN- $\gamma+\mathrm{H}_{2} \mathrm{O}_{2}$ & $1.98 \pm 0.03$ & $61.0 \pm 1.34$ & $18.6 \pm 1.56$ & $8.6 \pm 0.92$ & 0 & 0 & $5 \pm 1.37$ \\
\hline
\end{tabular}

NDI: nuclear division index; BiNC: binucleated cells; MultiNC: multinucleated cells; MoNC: mononucleated cells; MMC: Mitomycin C; IFN: interferon. 
The obtained results showed that the treated lymphocytes from healthy individuals with IFN- $\gamma$ bulk and IFN- $\gamma$ liposome did not induce significant DNA damage when compared to the untreated cells. However, when the same concentration of IFN- $\gamma$ in both forms was used on lung cancer patients' lymphocytes, DNA damage was reduced compared to the untreated cells. Still, the reduction of DNA damage that occurred by the liposome form of IFN- $\gamma$ was greater than from the IFN- $\gamma$ bulk (figures 2 and 3). This could possibly be due to the biocompatibility and enhanced cellular interaction of liposomes compared to their larger particles [44]. The Comet assay results showed that IFN- $\gamma$ bulk and the liposome form have a protective effect against $\mathrm{H}_{2} \mathrm{O}_{2}$, which induces damage in DNA due to oxidative stress in healthy individuals and lung cancer patients' lymphocytes. DNA damage significantly decreased compared to the PC. The effective results of IFN- $\gamma$ liposome against $\mathrm{H}_{2} \mathrm{O}_{2}$-induced damage could be due to the ability of liposome in preventing cell membrane alterations rather than its direct interaction with $\mathrm{H}_{2} \mathrm{O}_{2}$ [45].

The micronucleus assay was used to investigate the influence of IFN- $\gamma$ bulk and liposome on the lymphocytes from healthy individuals and lung cancer patients at the chromosomal level. The CBMN assay has been a critical test in detection of the genotoxicity of different compounds by measuring $\mathrm{MNi}$ and other chromosomal abnormalities such as NPBs, a biomarker of dicentric chromosomes, and by measuring NBUDs, which are a biomarker of gene amplification [46]. MNis are cytoplasmic bodies generated as a consequence of disorders during cell cycle division. Subsequently, when the centric fragments or whole chromosomes are incapable of travelling to opposite poles during anaphase, the nuclear envelope forms around the lagging chromosomes and fragments, which gradually take on the morphology of an interphase nucleus, which is smaller than the main nuclei in the cell [36, 47]. In this assay, the dividing cell cytokinesis is inhibited with cytochalasin B (Cyto B) [48].

In this study, amongst the different types of cells counted, specific consideration was made for the presence of $\mathrm{MNi}$ in the treatment groups because $\mathrm{MNi}$ are indicators of chromosomal breakage, loss, rearrangement, necrosis and apoptosis [35]. Furthermore, MNi in BiNC only showed the damage after treatment, which decreased the probability of scoring the pre-existing damage [49]. Mitomycin C (MMC) is recognised as an antitumour antibiotic, clastogenic and genotoxic compound. Therefore, MMC served as a PC in this study. MMC induced MNi production in BiNCs more than mononucleated cells (table 2). The percentage of BiNC after scoring 1000 cells was within the normal range in lymphocyte cultures for each individual. On the other hand, the percentage of MultiNC in cell culture was low, thus elucidating that cytochalasin B inhibited cell division after one cell cycle. Meanwhile, the NDI values were normal for all experiments (table 2).

From this assay, the frequency of $\mathrm{MNi}$ in the lymphocytes from healthy individuals and lung cancer patients decreased when treated with IFN- $\gamma$ and IFN- $\gamma$ liposome compared to the untreated cells (NC) for each group. In contrast, the IFN- $\gamma$ liposome showed a greater reduction in MNi frequency in lymphocytes. $\mathrm{H}_{2} \mathrm{O}_{2}$ was used in this assay and functioned as expected, inducing MNi production on the lymphocytes from both healthy individuals and lung cancer patients. The combination of IFN- $\gamma$ bulk and IFN- $\gamma$ liposome with $\mathrm{H}_{2} \mathrm{O}_{2}$ reduced the frequency of MNis compared to $\mathrm{H}_{2} \mathrm{O}_{2}$ in patients' lymphocytes. This study's most important finding was that IFN- $\gamma$ liposome had exhibited higher DNA damage reduction effects at $100 \mathrm{U} \cdot \mathrm{mL}^{-1}$ concentration than IFN- $\gamma$ bulk.

The Comet assay data showed that IFN- $\gamma$ in bulk and liposome form reduced DNA damage in the lymphocytes from healthy individuals and lung cancer patients compared to the NC.

Our results were consistent with a previous study where IFN- $\gamma$ induced early stimulation of PARP (the DNA repair enzyme) when the cells were exposed to a proapoptotic agent [50]. Furthermore, DNA damage was decreased when the IFN- $\gamma$ bulk and liposome were treated with $\mathrm{H}_{2} \mathrm{O}_{2}$ in the lymphocytes from healthy individuals and lung cancer patients compared to the PC. This denotes the ability of IFN- $\gamma$ to protect against DNA damage in lymphocytes from oxidative stress. The CBMN assay followed a similar pattern to the Comet assay results. It also showed a reduction in $\mathrm{MNi}$ frequency in the lymphocytes, thus implying the potential facilitation of DNA repair.

In general, IFN- $\gamma$ liposome $\left(100 \mathrm{U} \cdot \mathrm{mL}^{-1}\right)$ has shown better protective effects than its larger particle counterpart, bulk, at the same concentrations of $100 \mathrm{U} \cdot \mathrm{mL}^{-1}$ each. This could perhaps be due to the enhanced solubility of liposome-coated IFN- $\gamma$ in an aqueous medium stabilising various therapeutic agents such as proteins and nucleotides. Their size, surface charge and composition are favourable conditions for their effective results [51]. Many hydrophilic and hydrophobic biomolecules can be encapsulated in liposomes and protected from interactions with the external environment. Liposomes inhibit the metabolism of the drug before reaching the target cells plus protect the drug's interaction with healthy 
cells, enhancing the therapeutic index of the drug. It has been well documented that the liposome form of any therapeutic drug shows enhanced pharmacokinetic properties and biodistribution than its free form. The morphology of liposomes is similar to that of the cellular membranes, making them an ideal drug carrier system [44].

In conclusion, the data obtained from the Comet and micronucleus assays indicated that IFN- $\gamma$ in both forms might potentially be effective for lung cancer patients. Overall data from the present study proposes that IFN- $\gamma$ could protect and defend against lung cancer through cell cycle arrest of cancer cells and repair mechanisms and liposomes can potentially be used as an alternative, better drug delivery system in various conditions.

Acknowledgement: The authors would like to thank the clinical staff of Bradford Royal Infirmary and St Luke's Hospital for their assistance in this study.

Conflict of interest: None declared.

Support Statement: The sponsorship by the Mutah University of a PhD studentship to Maysa Alhawamdeh is gratefully acknowledged. The sponsor played no part in the conduct of the work or the writing of the manuscript. Funding information for this article has been deposited with the Crossref Funder Registry.

References

1 Travis WD. Pathology of lung cancer. Clin Chest Med 2002; 23: 65-81.

2 Lumb AB. Nunn's Applied Respiratory Physiology. 8th Edn. Amsterdam, Elsevier Health Sciences, 2016.

3 Ferlay J, Soerjomataram I, Dikshit R, et al. Cancer incidence and mortality worldwide: sources, methods and major patterns in GLOBOCAN 2012. Int J Cancer 2015; 136: E359-E386.

4 Chivima B. Lung cancer: a CPD article has improved Brenda Chivima's understanding of the care of patients with lung cancer. Nurs Stand 2015; 29: 61.

5 Ali N, Lifford KJ, Carter B, et al. Barriers to uptake among high-risk individuals declining participation in lung cancer screening: a mixed methods analysis of the UK Lung Cancer Screening (UKLS) trial. BMJ Open 2015; 5 : e008254.

6 Mitchell PD, Kennedy MP. Bronchoscopic management of malignant airway obstruction. Adv Ther 2014; 31: 512-538.

7 American Cancer Society. Cancer staging. www.cancer.org/treatment/understanding-your-diagnosis/staging. html Date last accessed: October 24, 2018.

8 Doll R, Peto R, Boreham J, et al. Mortality from cancer in relation to smoking: 50 years observations on British doctors. Br J Cancer 2005; 92: 426-429.

9 Peto R. Smoking, smoking cessation, and lung cancer in the UK since 1950: combination of national statistics with two case-control studies. BMJ 2000; 321: 323-329.

10 Parkin DM. 2. Tobacco-attributable cancer burden in the UK in 2010. Br J Cancer 2011; 105: S6.

11 Mojic M, Takeda K, Hayakawa Y. The dark side of IFN- $\gamma$ : its role in promoting cancer immunoevasion. Int $J$ Mol Sci 2017; 19: 89.

12 Castro F, Cardoso AP, Gonçalves RM, et al. Interferon-gamma at the crossroads of tumor immune surveillance or evasion. Front Immunol 2018; 9: 847.

13 Seif $\mathrm{F}$, Khoshmirsafa M, Aazami H, et al. The role of JAK-STAT signaling pathway and its regulators in the fate of T helper cells. Cell Commun Signal 2017; 15: 23.

14 Melmed S Polonsky KS Larsen PR, et al., eds. Williams Textbook of Endocrinology. 13th Edn. Amsterdam, Elsevier Health Sciences, 2015.

15 Krause CD, Lavnikova N, Xie J, et al. Preassembly and ligand-induced restructuring of the chains of the IFN-gamma receptor complex: the roles of Jak kinases, Stat1 and the receptor chains. Cell Res 2006; 16: 55-69.

16 Kulling PM Olson KC Hamele CE R, et al. Dysregulation of the IFN-gamma-STAT1 signaling pathway in a cell line model of large granular lymphocyte leukemia. PLoS One 2018; 13: e0193429.

17 Zaidi MR, Merlino G. The two faces of interferon-gamma in cancer. Clin Cancer Res 2011; 17: 6118-6124.

18 Bernabei P, Coccia EM, Rigamonti L, et al. Interferon- $\gamma$ receptor 2 expression as the deciding factor in human T, B, and myeloid cell proliferation or death. J Leukoc Biol 2001; 70: 950-960.

19 Rettino A, Clarke NM. Genome-wide identification of IRF1 binding sites reveals extensive occupancy at cell death associated genes. J Carcinog Mutagen 2013; S6: 1-10.

20 Gao Y, Yang J, Cai Y, et al. IFN-gamma-mediated inhibition of lung cancer correlates with PD-L1 expression and is regulated by PI3K-AKT signaling. Int J Cancer 2018; 143: 931-943.

21 Shen J, Xiao Z, Zhao Q, et al. Anti-cancer therapy with TNF $\alpha$ and IFN $\gamma$ : a comprehensive review. Cell Proliferation 2018; 51: e12441. 
22 Mishra G P, Bagui M, Tamboli V, et al. Recent applications of liposomes in ophthalmic drug delivery. J Drug Deliv 2011: 863734.

23 Laouini A, Jaafar-Maalej C, Limayem-Blouza I, et al. Preparation, characterization and applications of liposomes: state of the art. J Colloid Sci Biotechnol 2012; 1: 147-168.

24 Alavi M, Karimi N, Safaei M. Application of various types of liposomes in drug delivery systems. Adv Pharm Bull 2017; 7: 3-9.

25 Joshi S, Hussain M T, Roces C B, et al. Microfluidics based manufacture of liposomes simultaneously entrapping hydrophilic and lipophilic drugs. Int J Pharmaceut 2016; 514: 160-168.

26 Shi K, Li J, Cao Z, et al. A pH-responsive cell-penetrating peptide-modified liposomes with active recognizing of integrin av $\beta 3$ for the treatment of melanoma. J Controlled Release 2015; 217: 138-150.

27 Li F, Li Q-H, Wang J-Y, et al. Effects of interferon-gamma liposomes targeted to platelet-derived growth factor receptor-beta on hepatic fibrosis in rats. $J$ Control Release 2012; 159: 261-270.

28 Tice RR, Agurell E, Anderson D, et al. Single cell gel/comet assay: Guidelines for in vitro and in vivo genetic toxicology testing. Environ Mol Mutagen 2000; 35: 206-221.

29 Anderson D, Dobrzyńska MM, Basaran N. Effect of various genotoxins and reproductive toxins in human lymphocytes and sperm in the Comet assay. Teratoge Carcinog Mutagen 1997; 17: 29-43.

30 Singh NP, Mccoy MT, Tice RR, et al. A simple technique for quantitation of low levels of DNA damage in individual cells. Exp Cell Res 1988; 175: 184-191.

31 OECD. Test No. 489: In Vivo Mammalian Alkaline Comet Assay, 2016.

32 Najafzadeh M, Anderson D. The use of isolated peripheral lymphocytes and human whole blood in the comet assay. Protoc Exchange 2016; 5207.

33 Najafzadeh M, Normington C, Jacob BK, et al. DNA damage in healthy individuals and respiratory patients after treating whole blood in vitro with the bulk and nano forms of NSAIDs. Front Mol Biosci 2016; 3: 50.

34 Fenech M, Knasmueller S, Bolognesi C, et al. Molecular mechanisms by which in vivo exposure to exogenous chemical genotoxic agents can lead to micronucleus formation in lymphocytes in vivo and ex vivo in humans. Mutat Res Rev Mutat Res 2016; 770: 12-25.

35 Fenech M. Cytokinesis-block micronucleus cytome assay. Nat Protoc 2007; 2: 1084-1104.

36 Fenech M, Kirsch-Volders M, Natarajan A, et al. Molecular mechanisms of micronucleus, nucleoplasmic bridge and nuclear bud formation in mammalian and human cells. Mutagenesis 2011; 26: 125-132.

37 Bausinger J, Speit G. The impact of lymphocyte isolation on induced DNA damage in human blood samples measured by the comet assay. Mutagenesis 2016; 31: 567-572.

38 Chan LL-Y, Rice WL, Qiu J. Observation and quantification of the morphological effect of trypan blue rupturing dead or dying cells. PLoS One 2020; 15: e0227950.

39 Riss TL, Moravec RA, Niles AL, et al. Cell viability assays. Assay Guidance Manual. Eli Lilly \& Company and the National Center for Advancing Translational Sciences, 2016.

40 Henderson L, Wolfreys A, Fedyk J, et al. The ability of the Comet assay to discriminate between genotoxins and cytotoxins. Mutagenesis 1998; 13: 89-94.

41 Das A, Banik NL, Ray SK. Molecular mechanisms of the combination of retinoid and interferon-gamma for inducing differentiation and increasing apoptosis in human glioblastoma T98G and U87MG cells. Neurochem Res 2009; 34: 87-101.

$42 \mathrm{Wu} \mathrm{Y}$, Meitzler JL, Antony S, et al. Dual oxidase 2 and pancreatic adenocarcinoma: IFN- $\gamma$-mediated dual oxidase 2 overexpression results in $\mathrm{H} 2 \mathrm{O} 2$-induced, ERK-associated up-regulation of HIF- $1 \alpha$ and VEGF-A. Oncotarget 2016; 7: 68412-68433.

43 Razaghi A, Villacrés C, Jung V, et al. Improved therapeutic efficacy of mammalian expressed-recombinant interferon gamma against ovarian cancer cells. Exp cell Res 2017; 359: 20-29.

44 Bozzuto G, Molinari A. Liposomes as nanomedical devices. Int J Nanomed 2015; 10: 975-999.

45 Trif M, Craciunescu O. 12 Liposome as efficient system for intracellular delivery of bioactive molecules. Nanotechnol Funct Foods 2015; 191.

46 Cho YH, Kim YJ, Lee S, et al. Effects of the DNA repair inhibitors, cytosine arabinoside and 3-aminobenzamide, on the frequency of radiation-induced micronuclei, nuclear buds, and nucleoplasmic bridges. Genes Genomics 2020; 42: 673-680.

47 Luzhna L, Kathiria P, Kovalchuk O. Micronuclei in genotoxicity assessment: from genetics to epigenetics and beyond. Front Genet 2013; 4: 131.

48 Doherty A, Bryce SM, Bemis JC. Chapter 6 - The In Vitro Micronucleus Assay. In: Proudlock R, ed. Genetic Toxicology Testing. Boston, Academic Press, 2016.

49 Li Y, Chen DH, Yan J, et al. Genotoxicity of silver nanoparticles evaluated using the Ames test and in vitro micronucleus assay. Mutat Res Genet Toxicol Environ Mutagen 2012; 745: 4-10.

50 De Saint Jean M, Brignole F, Bringuier AF, et al. Effects of benzalkonium chloride on growth and survival of Chang conjunctival cells. Invest Ophthalmol Vis Sci 1999; 40: 619-630.

51 Barenholz Y, Peer D. Liposomes and other assemblies as drugs and nano-drugs: from basic and translational research to the clinics. J Control Release 2012; 160: 115-116. 